\title{
Fisikokimia, Mikrobiologi dan Organoleptik Yogurt Probiotik dengan Penambahan Buah merah (Pandanus conodeous L.)
}

\author{
Physicochemical, Microbiology and Organoleptic of Yoghurt Probiotik with Red Fruit \\ (Pandanus conodeuos L.) Addition
}

\author{
H. A. Jonathan*, I. N. Fitriawati, I. I. Arief, M. S. Soenarno, \& R. H. Mulyono
}

Departemen Ilmu Produksi dan Teknologi Peternakan, Fakultas Peternakan, Institut Pertanian Bogor

Jl. Agatis, Kampus IPB Darmaga Bogor 16680, Indonesia

*Corresponding author: hizkiajonathan20@gmail.com

(Received 04-09-2021; Revised 23-10-2021; Accepted 26-11-2021)

\begin{abstract}
Yogurt can be made from homogenized milk, low-fat milk or skimmed milk with the addition of powdered milk. Starter culture commonly used in yogurt is Lactobacillus bulgaricus and Streptococcus thermophillus can not survive in environments with high acidity, so probiotics needed. One of the fruits that can be used in the process of making yogurt is red fruit (Pandanus Conoideus $L$ ). The purpose of this study was to analyze the physical and organoleptic properties of probiotic yogurt given the addition of red fruit. The observed physical characteristics consist of $\mathrm{pH}$, viscosity, total acid concentration and water activity (aw) and organoleptic arachnids observed consisting of color, flavour, aroma and consistency. This research was using a complete randomized design (RAL). The results showed that the addition of red fruit has a real effect $(\mathrm{P}<0.05)$ on $\mathbf{p H}$, viscosity and total acid titrated and organoleptic test shows the addition of red fruit has a noticeable effect on color, flavour, aroma and viscosity in hedonic quality tests, then in hedonic tests affect aroma and flavour. Based on the results of yogurt testing with the addition of $\mathbf{2 . 5 \%}$ this is the closest to control and acceptable to Indonesian National Standards (SNI).
\end{abstract}

Keywords: characteristic organoleptic, and microbiology characteristic physicochemistry, probiotic, red fruit, yogurt

\begin{abstract}
ABSTRAK
Yogurt dapat dibuat dari susu yang telah dihomogenisasi, susu berkadar lemak rendah atau susu skim dengan penambahan susu bubuk. Kultur starter yang biasa digunakan dalam yogurt yaitu Lactobacillus bulgaricus dan Streptococcus thermophillus tidak dapat bertahan pada lingkungan dengan keasaman yang tinggi, sehingga diperlukan probiotik. Salah satu buah yang dapat ditambahkan adalah buah merah (Pandanus Conoideus $L$ ). Tujuan penelitian ini adalah menganalisis sifat fisik dan organoleptik yogurt probiotik yang diberi penambahan buah merah. Karakteristik fisik yang diamati terdiri atas pH, viskositas, total asam tertitrasi dan aktivitas air (aw) serta karakteristik organoleptik yang diamati terdiri atas warna, flavour, aroma dan kekentalan. Penelitian dilakukan dengan menggunakan rancangan acak lengkap (RAL). Hasil penelitian menunjukan bahwa penambahan buah merah berpengaruh nyata $(\mathbf{P}<0.05)$ terhadap $\mathrm{pH}$, viskositas dan total asam tertitrasi. Uji organoleptik memperlihatkan penambahan buah merah berpengaruh nyata terhadap warna, flavour, aroma dan kekentalan pada uji mutu hedonik, lalu pada uji hedonik berpengaruh pada aroma dan flavour. Berdasarkan hasil pengujian yogurt dengan penambahan $2.5 \%$ ini yang paling mendekati dengan kontrol dan memenuhi Standar Nasional Indonesia (SNI).
\end{abstract}

Kata kunci: buah merah, probiotik, sifat fisikokimia, sifat organoleptik dan mikrobiologi, yogurt 


\section{PENDAHULUAN}

Yogurt ada dua pilihan di masyarakat yaitu plain yogurt dan fruit yogurt. Plain yogurt adalah yogurt hasil fermentasi susu dengan menggunakan kultur Lactobacillus bulgaricus, dan Streptococcus thermophilus, sedangkan fruit yogurt adalah yogurt yang dalam proses pembuatannya dilakukan penambahan sari buah, daging buah, atau bagian buah lainnya sebagai penambah cita rasa, warna dan aroma sehingga meningkatkan sifat organoleptik yogurt (Tamime 2007). Salah satu buah yang dapat digunakan pada proses pembuatan yogurt adalah buah merah (Pandanus Conoideus $L)$.

Buah merah atau yang dikenal dengan nama latin Pandanus Conoideus $L$ merupakan tumbuhan endemik di Papua. Buah merah diketahui memilki manfaat bagi kesehatan berdasarkan beberapa penelitian diketahui bahwa semua ekstrak dan minyak dari buah merah dapat menyebabkan peningkatan proliferasi sel limfosit sehingga dapat meningkatkan imumunomodulator. Buah merah berasal dari famili pandanaceae, tumbuh di daerah pegunungan seperti Jayawijaya, Nabire, Timika dan Manokwari. Tanaman ini telah lama dibudayakan secara alami oleh masyakarat papua (Lisangan 2005). Bahkan buah merah juga telah dibudidayakan di kebun percobaan Amban Partai milik Universitas Negeri Papua (Renwarin 2002). Pada akhir. tahun 2004, sari buah merah terkenal sebagai suplemen yang dapat mengobati berberapa jenis penyakit, di antara kanker dan AIDS (Budi dan Paimin 2004). Terdapat 4 jenis buah merah pendek yang biasa dimanfaatkan oleh masyarakat yaitu, buah merah pendek, buah merah panjang, buah merah coklat, dan buah merah kuning.

Kultivar buah merah selain biasa dimanfaatkan sebagai sumber lemak nabati, digunakan juga sebagai campuran makanan maupun zat pewarna alami dan limbah hasil pengolahannya dapat dimanfaatkan sebagai bahan campuran untuk pakan ternak. Selain dimanfaatkan sebagai pangan, buah merah dapat digunakan sebagai prasarana mas kawin pernikahan oleh masyarakat adat setempat dan limbahnya dimanfaatkan untuk pengendalian semut merah bagi tanaman biji jagung, biji labu, dan biji ketimun (Indou 2003). Kultivar buah merah panjang memiliki potensi besar sebagai bahan baku industri pangan dan obatobatan, dikarenakan buah merah mengandung beta karoten, tokoferol (vitamin E), dan beberapa senyawa aktif lainnya yang hingga saat ini masih dalam tahap penelitian (Lisangan 2005).

Oleh karena itu, Yoghurt dengan penambahan buah merah sangat baik untuk diteliti. Hal ini dikarenakan potensi buah merah yang sangat tinggi untuk dikembangkan. Penelitian kali ini bertujuan untuk menganalisis sifat fisik dan organoleptik yogurt probiotik yang diberi penambahan yaitu buah merah.

\section{MATERI DAN METODE}

Materi
Penelitian ini dilaksanakan di Laboratorium
Ilmu Produksi dan Teknologi Peternakan Terpadu, dan
Laboratorium Hasil Ternak, Institut Pertanian Bogor.

Alat yang digunakan berupa kompor, panci, termometer, timbangan digital, spatula, inkubator, rotary evaporator, hot plate, shaker, pisau, sendok, dan wadah plastik. Peralatan yang digunakan dalam pengujian sifat fisik dan organoleptik yaitu $\mathrm{pH}$ meter, viscotester Rion VT04F, timbangan analitik, gelas arloji, labu ukur $1000 \mathrm{ml}$, labu ukur $100 \mathrm{ml}$, erlenmeyer $100 \mathrm{ml}$, erlenmeyer 250, pipet tetes, gelas ukur $100 \mathrm{ml}$, corong gelas, botol semprot, buret dan kuesioner uji organoleptic.

Bahan baku dalam pembuatan yogurt adalah susu, kultur bakteri Streptococcus salivarius subsp. Thermophilus, dan Lactobacillus delbrueckii subsp. Bulgaricus, Lactobacillus acidophilus IIA-2B4 dan ekstrak buah merah. Bahan pengujian yang digunakan seperti larutan buffer $\mathrm{pH}$ 4 dan 7, alkohol, tissue, larutan $\mathrm{NaOH} 0.1 \mathrm{~N}$, indikator fenolftalien 1\% dan Buffer Pepton Water (BPW).

Prosedur penelitian ini meliputi pembuatan ekstrak buah merah, pembuatan yoghurt, analisis fisikokimia, mikrobiologi dan organoleptik.

\section{Metode}

\section{Ekstraksi Buah Merah}

Buah merah segar dipisahkan dari empulurnya lalu ditimbang sebanyak \pm 100 gram, kemudian di potong kecil-kecil, dimaserasi di dalam air $500 \mathrm{ml}$ dengan digoyang menggunakan shaker pada suhu $\pm 29^{\circ} \mathrm{C}$ selama 72 jam, selanjutnya residu dimaserasi lagi di dalam air $350 \mathrm{ml}$ selama 24 jam, kemudian dimaserasi dengan air $250 \mathrm{ml}$ selama 24 jam, lalu disaring. Langkah selanjutnya maserat tersebut dilakukan evaporasi di dalam rotary evaporator, untuk membantu pengeringan, dilakukan penguapan menggunakan hot plate pada suhu $45^{\circ} \mathrm{C}$, ekstrak yang terjadi ditimbang.

\section{Peremajaan Bakteri}

Penyegaran kultur bakteri berguna untuk menyegarkan kultur yang sudah ada. langkah pertama adalah menginokulasikan kultur bakteri menggunakan perbandingan 1:9 ke dalam susu yang disterilisasi terlebih dahulu pada autoclave dengan suhu $115^{\circ} \mathrm{C}$ selama 3 menit. Selanjutnya susu yang telah dionkulasi oleh bakteri asam laktat diinkubasi pada suhu $37{ }^{\circ} \mathrm{C}$ selama 18 jam sampai membentuk koagulasi. Peremajaan bakteri ini dilakukan agar bakteri yang kita miliki segar dan tidak mengalami dorman.

\section{Pembuatan Yogurt dan Penambahan Ekstrak Buah Merah}

Susu sapi dipanaskan dengan suhu $85-90{ }^{\circ} \mathrm{C}$ selama 35 menit, langkah berikutnya susu didinginkan hingga mencapai suhu $40-45^{\circ} \mathrm{C}$. Starter streptococcus thermophilus, lactobacillus bulgaricus, dan Lactobacillus acidophilus IIA-2B4 ditambahkan pada susu sapi. Penambahan kultur starter sebanyak 3\% (v/v) dengan populasi yang digunakan adalah lebih dari $10^{7} \mathrm{CFU} \mathrm{mL}^{-1}$. Susu kemudian diinkubasi pada suhu $37^{\circ} \mathrm{C}$ selama 16 jam sampai terbentuk koagulasi. Setelah itu ditambahkan ekstrak buah merah sebanyak $0 \%$ (P1); $2.5 \%$ (P2); 5 \% (P3) dari volume susu (Tabel 1). Yogurt disimpan dalam suhu dingin $\left( \pm 4^{\circ} \mathrm{C}\right)$ dengan lama waktu penyimpanan yang berbeda (Donker et al. 2006). 
Tabel 1. Persentase formulasi yogurt buah merah

\begin{tabular}{lccc}
\hline \multirow{2}{*}{\multicolumn{1}{c}{ Jenis bahan }} & \multicolumn{3}{c}{ Bobot (ml) } \\
\cline { 2 - 4 } & $\mathrm{T} 1$ & $\mathrm{~T} 2$ & $\mathrm{~T} 3$ \\
\hline Buah merah & 0 & $50 \mathrm{ml}$ & $75 \mathrm{ml}$ \\
Susu segar & 500 & 500 & 500 \\
Streptococcus thermophillus & $7.5 \mathrm{ml}$ & $7.5 \mathrm{ml}$ & $7.5 \mathrm{ml}$ \\
Lactobacillus bulgaricus & $7.5 \mathrm{ml}$ & $7.5 \mathrm{ml}$ & $7.5 \mathrm{ml}$ \\
Lactobacillus acidophillus & $7.5 \mathrm{ml}$ & $7.5 \mathrm{ml}$ & $7.5 \mathrm{ml}$ \\
\hline
\end{tabular}

Keterangan: perlakuan yang digunakan adalah persentase dari bobot susu segar; T1: 0\% Buah merah ; T2: 2.5\% Buah merah; dan T3: 5\% buah merah. Persentase berdasarkan dari bobot susu segar.

\section{Analisis Sifat Fisik}

Nilai pH (AOAC 2005). Nilai $\mathrm{pH}$ diukur menggunakan $\mathrm{pH}$ meter. Alat $\mathrm{pH}$ meter dikalibrasi pada $\mathrm{pH} 4$ dan 7. Elektroda dimasukan pada yogurt dan dibiarkan hingga angka yang tertera pada ph meter tidak menunjukan pergesaran angka.

Nilai $A_{w}$ (AOAC 2005). Pengukuran $A_{w}$ yogurt diukur menggunakan $\mathrm{A}_{\mathrm{w}}$ meter yang telah dikalibrasi. $2 \mathrm{ml}$ yogurt kemudian diletakkan di dalam cawan pengukur. Alat dijalankan sampai menunjukkan tanda completed.

Total Asam Tertitrasi (AOAC 2005). Persentase asam laktat pada penelitian ini menggunakan metode titrasi. 10 ml sampel ditambahkan dengan 2 tetes indikator fenolftalien $1 \%$ hal selanjutnya dititrasi oleh larutan $\mathrm{NaOH} 0,1 \mathrm{~N}$ sampai muncul warna merah muda. Jumlah asam yang diproduksi pada proses fermentasi dapat dihitung dengan rumus:

$$
\text { TAT }(\% \text { Asam Laktat })=\text { NxV1xEq. Wt V2x10 }
$$

Keterangan :

$\mathrm{N} \quad=$ Normalitas Titran $(\mathrm{mol} \mathrm{L}-1)$

V1 = Volume Titran $(\mathrm{mL})$

V2 = Volume Sampel $(\mathrm{mL})$

Eq.Wt $=$ Berat equivalen asam (asam laktat $=90.8)$

\section{Pengukuran Aktivitas Air ( $\left.A_{w}\right)$ (Syarif 1992)}

Hal pertama yang dilakukan adalah Alat dikalibrasi dengan menggunakan larutan $\mathrm{NaCl}$ jenuh. Larutan $\mathrm{NaCl}$ jenuh dimasukkan ke dalam chamber pengukuran, langkah selanjutnya alat dinyalakan dengan menekan tombol start dan ditunggu sampai $A_{w}$ terbaca 0.750-0.752. Langkah berikutnya sampel dimasukkan ke dalam chamber, kemudian tombol start ditekan pada $\mathrm{A}_{\mathrm{w}}$ meter dan tunggu hingga nilai $\mathrm{A}_{\mathrm{w}}$ terbaca.

\section{Uji Organoleptik}

Pengujiankarakteristikorganoleptikinimenggunakan uji hedonik dan mutu hedonik. Uji hedonik dilakukan untuk mengetahui respon kesukaan panelis terhadap sifatsifat yang lebih spesifik seperti warna, aroma, rasa dan kekentalan (Setyaningsih et al. 2010). Uji mutu hedonik ini digunakan dalam pengidentifikasian karakteristik sensori penting pada produk serta memberikan informasi mengenai tingkat atau intensitas karakteristik tersebut (Permadi et al. 2018). Uji hedonik dan mutu hedonik produk yogurt yang dihasilkan dalam penelitian ini dilakukan berdasarkan Rahayu dan Nurosiyah (2008). Sampel disajikan di dalam cup plastik dengan ukuran seragam. Panelis untuk uji ini terdiri dari 50 orang panelis tidak terlatih. Empat atribut yang dinilai pada uji hedonik dan mutu hedonik antara lain warna, aroma, kekentalan, dan rasa. Pada form, uji hedonik dan mutu hedonik terdiri dari 5 skala penilaian pada setiap atribut yang dinilai.

\section{Analisis Sifat Kimia}

Analisis proksimat dilakukan menggunakan metode AOAC (2005) yang telah dimodifikasi. Analisis proksimat Yang dilakukan adalah kadar air, kadar abu, kadar protein, kadar lemak dan kadar karbohidrat. Persentase kadar air, kadar abu, kadar protein, dan kadar lemak dihitung menggunakan rumus manual. Kadar karbohidrat sampel dihitung dengan menggunakan metode analisis karbohidrat dari persentase analisis proksimat kadar air, kadar abu, kadar protein, dan kadar lemak.

\section{Analisis Mikrobiologi}

Tahap awal analisis mikrobiologi adalah pengenceran sampel masukan $1 \mathrm{ml}$ sampel yogurt dalam 9 $\mathrm{mL}$ buffer pepton water dan dihomogenkan dengan vortex selama 1-2 menit. Sebanyak $1 \mathrm{~mL}$ suspensi dipindahkan ke dalam larutan $9 \mathrm{~mL}$ BPW untuk mendapatkan pengenceran . Pengenceran dilanjutkan hingga pengenceran . Larutan yang telah diencerkan digunakan untuk pengujian Angka Lempeng Total. Angka Lempeng Total (Blodgett 2006). Suspensi $1 \mathrm{~mL}$ dari pengenceran - dimasukkan dalam cawan petri secara duplo. Media Plate Count Agar dituang sebanyak 15-20 mL ke dalam cawan dengan suhu $45 \pm 1{ }^{\circ} \mathrm{C}$.

\section{Analisis Statistik}

Data dianalisis menggunakan analisis sidik ragam (ANOVA) untuk Rancangan Acak Kelompok (RAK) dengan perlakuan penambahan buah merah pada konsentrasi yang berbeda dan dengan tiga kali pengulangan (Steel dan Torrie 1997). Taraf perlakuan yang berbeda nyata maka akan di uji lanjut tukey. Data hasil uji organoleptik dianalisis menggunakan uji non parametrik Kruskal-Wallis. Taraf perlakuan yang berbeda atau sangat berbeda, dilakukan uji beda nilai tengah menggunakan uji Mann Whitney.

\section{HASIL DAN PEMBAHASAN}

\section{Kualitas Fisik Yogurt Probiotik dengan Penambahan Buah Merah}

Karakteristik fisik yang diuji pada penelitian ini adalah $\mathrm{pH}$, Aw, total asam tertirasi dan kekentalan. Nilai rataan hasil uji sifat yogurt probiotik dengan penambahan buah merah terdapat pada Tabel 2. Hasil analisis yang dilakukan pada penelitian ini menunjukan bahwa penambahan buah merah memiliki pengaruh yang nyata terhadap karakteristik fisik yogurt probiotik.

\section{Nilai pH}

Nilai pH adalah karakteristik fisik untuk menampilkan suatu produk dalam hal ini yogurt. Nilai $\mathrm{pH}$ adalah ukuran kadar keasaman dan kebasaan pada suatu sistem cairan. Nilai pH suatu cairan ditentukan dari besarnya konsentarasi 
Tabel 2. Kualitas fisik yoghurt probiotik dengan penambahan buah merah

\begin{tabular}{lccc}
\hline \multicolumn{1}{c}{ Kualitas } & \multicolumn{3}{c}{ Perlakuan } \\
\cline { 2 - 4 } \multicolumn{1}{c}{ Fisik } & $\mathrm{T} 1$ & $\mathrm{~T} 2$ & $\mathrm{~T} 3$ \\
\hline $\mathrm{pH}$ & $4.47 \pm 0.04 \mathrm{a}$ & $4.56 \pm 0.06 \mathrm{ab}$ & $4.60 \pm 0.05 \mathrm{~b}$ \\
$\mathrm{~A}_{\mathrm{w}}$ & $0.86 \pm 0.01 \mathrm{a}$ & $0.86 \pm 0.01 \mathrm{a}$ & $0.86 \pm 0.01 \mathrm{a}$ \\
Viskositas & $12.70 \pm 0.60 \mathrm{a}$ & $10.00 \pm 0.00 \mathrm{~b}$ & $8.20 \pm 0.30 \mathrm{c}$ \\
TAT & $0.55 \pm 0.02 \mathrm{a}$ & $0.52 \pm 0.02 \mathrm{ab}$ & $0.50 \pm 0.01 \mathrm{~b}$ \\
\hline
\end{tabular}

T1: penambahan buah merah $0 \%$; T2: penambahan $2.5 \%$ buah merah; T3: penambahan 5\% buah merah; Angka-angka pada baris yang sama yang diikuti oleh huruf yang sama maka tidak berbeda nyata pada taraf uji $5 \%$.

ion $\mathrm{H}^{+}$dan $\mathrm{OH}^{-}$didalamnya. Penggunaan bakteri asam laktat dalam pembuatan yogurt akan menghasilkan asam laktat sebagai hasil dari fermentasi laktosa yang terkandung dalam susu (Isengrad 2009). Hasil analisis pada penelitian kali ini (Tabel 1) menunjukan bahwa penambahan buah merah berpengaruh nyata terhadap nilai $\mathrm{pH}$ yogurt.

Nilai $\mathrm{pH}$ yogurt tertinggi diperoleh pada perlakuan penambahan buah merah (5\%) dengan kisaran nilai 4.554.65 sedangkan nilai $\mathrm{pH}$ terendah pada perlakuan kontrol (0\%) dengan nilai $\mathrm{pH}$ 4.43-4.51 dan penambahan buah merah (2.5\%) memiliki nilai $\mathrm{pH} 4.50-4.62$. Menurut SNI 2009, syarat mutu yogurt yang baik memiliki nilai $\mathrm{pH}$ berkisar antara 3.80-4.50. Hal ini membuat produk yogurt probiotik dengan penambahan buah merah masih sedikit diatas SNI yogurt. Semakin tinggi proporsi penambahan buah merah (Pandanus conodeus L.) yang di tambahkan kedalam produk olahan susu yaitu yogurt maka nilai $\mathrm{pH}$ yogurt yang dihasilkan akan semakin tinggi. Peningkatan $\mathrm{pH}$ ini disebabkan karena adanya peningkatan konsentrasi buah merah yang bersifat tidak terlalu asam dengan $\mathrm{pH}$ (5.70) sehingga berpengaruh terhadap peningkatan $\mathrm{pH}$ yogurt. Nilai ph lambung dalam keadaan istirahat yaitu sekitar 2.0. Berdasarkan hal tersebut dapat diasumsikan bahwa produk yogurt probiotik dengan penambahan buah merah yang dihasilkan aman untuk dikonsumsi karena nilai ph yogurt yang dihasilkann tidak lebih asam dari $\mathrm{pH}$ lambung.

\section{Nilai TAT}

Nilai total asam tertirasi artinya jumlah asam laktat yang terdapat dalam yogurt. Bedasarkan data pada Tabel 2 menunjukkan bahwa besarnya nilai total asam tertirasi berbanding terbalik dengan nilai $\mathrm{pH}$. Hasil analisis ragam menunjukkan bahwa penambahan buah merah pada yogurt probiotik nyata $(\mathrm{P}<0.05)$ terhadap nilai total asam tertirasi. Nilai total asam tertirasi pada yogurt dengan penambahan buah merah berkisar antara $0.50-0.55 \%$.

Nilai TAT pada penelitian kali ini masih memenuhi nilai standar SNI Mutu Yogurt (BSN 2009) yaitu nilai TAT sebesar $0.5-2.0 \%$. Yogurt probiotik tanpa penambahan buah merah memiliki nilai total asam tertirasi yang lebih tinggi dibandingkan dengan yogurt probiotik dengan penambahan buah merah. Hal ini disebabkan $\mathrm{pH}$ yang dimiliki oleh tanpa penambahan buah merah tinggi. Kandungan laktosa yang tinggi juga menyebabkan terbentuknya asam laktat yang tinggi sebagai hasil dari fermentasi laktosa oleh bakteri asam laktat. Aktivitas fermentasi yang dilakukan oleh BAL selama pembuatan yogurt menyebabkan akumulasi produk asam laktat yang dihasilkan sehingga nilai total asam tertirasi yogurt probiotik dapat meningkat.

Nilai $\mathbf{A}_{\mathbf{w}}$

Hasil analisis ragam pada Tabel 2 menunjukkan bahwa penambahan buah merah pada yogurt probiotik berpengaruh tidak nyata $(\mathrm{P}>0.05)$ terhadap $\mathrm{A}_{\mathrm{w}}$ yogurt. Nilai $\mathrm{A}_{\mathrm{w}}$ hasil pengujian dari ketiga jenis yogurt probiotik dengan taraf penambahan buah merah yang berbeda berkisar antara 0.85-0.86. Hal ini sesuai dengan beberapa penelitian bahwa yogurt memiliki nilai A $0.85-0.860$ (Melanie 2018). Menurut Rahayu (2012) yogurt dapat dirusak oleh mikroorganisme dari dua jenis yaitu jenis khamir atau ragi. Hal ini dapat menunjukkan pada kisaran $\mathrm{A}_{\mathrm{w}}$ yogurt buah merah dapat menumbuhkan mikroorganisme yaitu ragi. Menurut Frazier (2009) mengungkapkan bahwa pertumbuhan bakteri patogen seperi Salmonella, Escherichia dan Clostridia terhambat pada $\mathrm{A}_{\mathrm{w}}<0.91$, ragi terhambat pada $\mathrm{A}_{\mathrm{w}}<0.87$ dan kapang terhambat pada $\mathrm{Aw}<0.80$ serta pada $\mathrm{A}_{\mathrm{w}}<0.60$ hampir tidak memungkinkan mikroba tumbuh. Jay et al. (2005) menambahkan bakteri yang dapat tumbuh pada nilai $\mathrm{A}_{\mathrm{w}} 0.86$ adalah Staphylococcus aureus.

\section{Viskositas}

Nilai viskositas yang terukur terendah diperoleh pada perlakuan penambahan buah merah $(5 \%)$ dengan kisaran nilai 7.9-8.5 cP dan perlakuan yang memiliki viskositas tertinggi yaitu pada perlakuan kontrol $(0 \%)$ dengan nilai viskositas 12.1-13.3 cP. Hal ini sesuai dengan pendapat (Winarno 2007) bahwa produk fermentasi yang mengacu pada yogurt mempunyai viskositas antara 8.28-13.00 cP. Hal ini mungkin disebabkan karena kondisi $\mathrm{pH}$ yang asam. Nilai pH dapat menurunkan kelarutan kasein, sehingga terjadi interaksi hidrofobik antara misel kasein membentuk struktur dan konsistensi yogurt drink yang menyebabkan yogurt drink makin kental sehingga viskositas naik. Menurut Muchtadi dan Sugiyono (1992) viskositas adalah besarnya hambatan suatu cairan terhadap aliran dan pengadukan. (Susanto 2001) menambahkan bahwa viskositas adalah suatu hambatan yang menahan zat cair secara molekul yang disebabkan oleh gerakan acak molekul zat cair tersebut. Peningkatan viskositas terjadi disebabkan eningkatan jumlah eksopolisakarida (EPS). Eksopolisakarida yaitu polisakarida yang dihasilkan oleh BAL pada kondisi lingkungan yang cukup ekstrim (Nudyanto 2014). EPS ini digunakan bakteri untuk dapat bertahan hidup menempel pada permukaan dan mencegah dari kekeringan.

Perbedaan nilai viskositas diantara ketiga jenis yogurt tersebut dipengaruhi oleh penambahan buah merah. Yogurt yang diberi penambahan buah merah memiliki viskositas yang rendah dikarenakan ekstrak buah merah ini sangat cair. Hal inilah yang menyebabkan viskositas yogurt menjadi encer. Asumsi lain terdapat perbedaan viskositas dikarenakan nilai $\mathrm{pH}$. Nilai $\mathrm{pH}$ yogurt probiotik tanpa penambahan buah merah (Tabel 2) lebih rendah dari titik isoelektris sehingga menyebabkan terbentuknya koagulan yang lebih kental. Djaafar (2006) menyatakan nilai $\mathrm{pH}$ yang lebih rendah dari titik isoelektris (4.4-4.5) tersebut 
menyebabkan protein pada susu mengalami penggumpalan. Hal ini sesuai dengan pendapat Wahyudi (2008) bahwa terbentuknya asam laktat menyebabkan peningkatan total asam sehingga kasein mengalami koagulasi pembentuk gel. Terbentuknya gel menyebabkan tekstur menjadi semi padat sehingga viskositasnya naik. Namun, dalam penelitian ini titik isolektrik bukan menjadi faktor viskositas yogurt menjadi rendah. Hal ini dikarenakan penambahan buah merah yang dilakukan saat telah menjadi yogurt.

\section{Karakteristik Kimia Yogurt Probiotik dengan Penambahan Buah Merah}

Karakteristik kimia yang diuji pada penelitian ini adalah kadar air, kadar abu, kadar lemak, kadar protein, dan kadar karbohidrat. Nilai rataan hasil uji sifat yoghurt probiotik dengan penambahan buah merah dapat dilihat pada Tabel 3. Hasil analisis ragam menunjukan bahwa penambahan buah merah tidak memberikan pengaruh terhadap karakteristik kimia yogurt probiotik dengan penambahan buah merah.

\section{Kadar Air}

Kandungan air dalam bahan makanan ikut menentukan akseptabilitas, kesegaran dan daya tahan bahan terhadap serangan mikroba (Winarno 2002). Rataan kadar air yogurt probiotik dengan buah merah pada penelitian ini berkisar $88.86 \%-89.13 \%$ dan menunjukan nilai yang tidak berbeda nyata $(\mathrm{P}>0.05)$ (Tabel 3). Kadar air merupakan suatu faktor yang mempengaruhi ekstrak buah merah bila akan diaplikasikan pada produk pangan. Karena kadar air yang cukup tinggi secara mikrobiologis dan kimiawi dapat menentukan umur simpan dari suatu produk.

Bakteri akan mepunyai kesempatan untuk dapat berkembang biak dengan cepat pada lingkungan yang tinggi kadar airnya. Secara kimiawi kandungan oksigen pada air yang tersisa saat ekstraksi dapat memicu terjadinya lemak terhidrolisis sheingga menghasilkan gliserol dan asam lemak. Proses hidrolisis dapat terjadi sangat cepat bila ekstrak buah merah mempunyai kadar air dengan nilai yang cukup tinggi (Ketaren 1986).

\section{Kadar Abu}

Kadar abu merupakan komponen zat anorganik prosesnya bertujuan menentukan jumlah mineral sisa pembakaran tersebut disebut pengabuan. Hasil analisis statistik pada Tabel 3 bahwa perlakuan (P0, P1, P2) menunjukkan hasil statistik tidak adanya perbedaan (P $>0.05$ ) antar perlakuan. Hasil pengabuan menunjukkan hasil terendah berkisar $0.52-0.57 \%$ hal ini menunjukkan hasil pengujian telah memenuhi dengan standar SNI (2009). (Robinson et al. 2002) menambahkan, aktivitas metabolit kultur minuman prebiotic dapat meningkatkan bioavailabilitas jenis vitamin tertentu dan kandungan mineral juga meningkat kecernaan protein. Peningkatan vitamin ini ini telah diteliti oleh (Stepaniak dan Fetlinski 2002) yang menyebutkan kandungan vitamin B1 dan B2 juga asam folat pada kefir lebih tinggi jika di komparasi dengan susu.

\section{Kadar Lemak}

Kadar lemak pada yogurt probiotik dengan panambahan buah merah berkisar antara 3.30\%-4.04\% dan tidak menunjukan adanya perbedaan kadar lemak di setiap yogurt probiotik yang ada $(\mathrm{P}>0.05)$ (Tabel 3). Kadar lemak yogurt probiotik dengan penambahan buah merah pada penelitian ini telah memenuhi syarat SNI yaitu maksimal 3\% (Badan Standardisasi Nasional 2009).

\section{Kadar Protein}

Kadar protein yogurt probiotik penambahan buah merah berkisar antara $2.60 \%-2.84 \%$ dan hasil ini menunjukkan bahwa kadar protein yogurt tidak berbeda nyata antar perlakuan $(\mathrm{P}>0.05)$ (Tabel 4). Batas minimum kadar protein yogurt sesuai SNI adalah 2.7, dengan demikian kadar protein yogurt probiotik penambahan buah merah T1 (0\%) dan T3 (5\%) kurang dari syarat SNI. Hal ini dipengaruhi oleh rendahnya kadar protein pada bahan baku yang digunakan.

\section{Kualitas Mikrobiologi Yogurt Probiotik dengan Penambahan Buah Merah}

Bakteri Asam Laktat (BAL) merupakan agen utama dalam proses fermentasi, BAL memanfaatkan kandungan laktosa pada susu untuk menghasilkan asam laktat (Chandan et al. 2006). Pada penelitian penambahan ekstrak buah merah menunjukkan hasil Analisa statistik perlakuan (P0, P1, P2) dengan konsentrasi berbeda menunjukkan tidak adanya perbedaan $(\mathrm{P}>0.05)$ antar perlakuan. Jumlah bakteri asam laktat (BAL) merupakan indikator kualitas mikrobiologis sebuah produk susu fermentasi. Diketahui jumlah total bakteri asam laktat pada perlakuan (T1, T2, T3) berturut turtut adalah $9.63 \times 10^{9} \mathrm{CFU} / \mathrm{mL}, 9.66 \times 10^{9} \mathrm{CFU} /$

Tabel 3. Sifat kimia yogurt dengan penambahan buah merah

\begin{tabular}{|c|c|c|c|c|}
\hline \multirow{2}{*}{ Analisis Kimia } & \multicolumn{3}{|c|}{ Perlakuan } & \multirow{2}{*}{$\begin{array}{c}\text { SNI Yogurt Probiotik } \\
\text { (SNI 3820-2015) } \\
(\%)\end{array}$} \\
\hline & $\mathrm{T} 1(\%)$ & $\mathrm{T} 2(\%)$ & T3 (\%) & \\
\hline Kadar Lemak (b/b) & $3.60 \pm 0.24$ & $3.35 \pm 0.60$ & $4.04 \pm 0.09$ & Min 3.0 \\
\hline Total padatan susu bukan lemak & $7.28 \pm 0.23$ & $7.75 \pm 0.56$ & $7.10 \pm 0.22$ & Min 8.2 \\
\hline Kadar Protein (b/b) & $2.67 \pm 0.09$ & $2.84 \pm 0.21$ & $2.60 \pm 0.07$ & Min 2.7 \\
\hline Kadar Air (b/b) & $89.13 \pm 0.36$ & $88.90 \pm 0.13$ & $88.86 \pm 0.13$ & - \\
\hline Kadar Abu (b/b) & $0.54 \pm 0.14$ & $0.53 \pm 0.13$ & $0.59 \pm 0.04$ & Maks 1.0 \\
\hline
\end{tabular}

T1: penambahan buah merah $0 \%$; T2: penambahan 2.5\% buah merah; T3: penambahan 5\% buah merah; Angka-angka pada kolom yang sama yang diikuti oleh huruf yang sama tidak berbeda nyata pada taraf uji $5 \%$. 
$\mathrm{mL}$, dan $9.41 \times 10^{9} \mathrm{CFU} / \mathrm{mL}$ (Tabel 4). Nilai BAL tersebut mengalami penurunan namun tidak signifikan hal ini dapat disebabkan oleh sifat ekstrak buah merah yang anti mikroba sehingga penamahan ekstrak dengan konstentrasi berbeda akan mempengaruhi.

Tabel 4. Angka lempeng total yogurt probiotik dengan penambahan buah merah

\begin{tabular}{cc}
\hline Pelakuan & Angka Lempeng Total $\left(\right.$ Log $\left.\mathrm{cfu} \mathrm{g}^{-1}\right)$ \\
\hline T1 & $9.63 \pm 0.22$ \\
T2 & $9.66 \pm 0.38$ \\
T3 & $9.41 \pm 0.01$ \\
\hline
\end{tabular}

T1: penambahan buah merah $0 \%$; T2: penambahan $2.5 \%$ buah merah; T3: penambahan 5\% buah merah; Angka-angka pada baris yang sama yang diikuti oleh huruf yang sama tidak berbeda nyata pada taraf uji $5 \%$.

\section{Organoleptik Yogurt Probiotik dengan Penambahan Buah merah}

Uji organoleptik yang dilakukan pada penelitian ini terdapat dua uji yaitu uji heodnik dan uji mutu hedonik (Tabel 5). Pengujian organoleptic yang dilakukan dengan pengambilan data dari 30 orang panelis semi terlatih terhadap sampel warna, bau, flavour, dan kekentalan. Sampel yang digunakan adalah yogurt probiotik dengan penambahan buah merah $0 \%$ (kontrol), 2.5\% dan 5.0\%).

\section{Aroma}

Penilaian aroma dengan menggunakan alat indera yaitu penciuman. Alat indera ini akan menangkap senyawa volatil atau senyawa yang mudah menguap yang terdapat pada produk (Stefani 2008). Aroma juga merupakan persepsi olfaktori yang dapat menangkap komponen kimia yang dapat dirasakan oleh lidah. Hasil uji hedonik pada penambahan buah merah berpengaruh nyata terhadap produk $(\mathrm{P}<0.05)$. Hasil uji hedonik ini menunjukan bahwa penambahan buah merah dengan konsentrasi 5\% kurang disukai oleh panelis dengan nilai 2.73 (tidak disukai). Hal ini dikarenakan bau buah merah yang terlalu banyak membuat produk yogurt menjadi sangat berbau lemak. Menurut Ayomi (2015) kandungan utama sari buah merah adalah asam lemak. Asam lemak yang terdapat dalam sari buah merah terdiri atas asamr palmitat, asam oleat, asam linoleat, dan asam linolenat.

Penilaian aroma dengan menggunakan alat indera yaitu penciuman. Alat indera ini akan menangkap senyawa volatil atau senyawa yang mudah menguap yang terdapat pada produk (Stefani 2008). Aroma juga merupakan persepsi olfaktori yang dapat menangkap komponen kimia yang dapat dirasakan oleh lidah. Hasil uji hedonik pada penambahan buah merah berpengaruh nyata terhadap produk $(\mathrm{P}<0.05)$. Hasil uji hedonik ini menunjukan bahwa penambahan buah merah dengan konsentrasi 5\% kurang disukai oleh panelis dengan nilai 2.73 (tidak disukai). Hal ini dikarenakan bau buah merah yang terlalu banyak membuat produk yogurt menjadi sangat berbau lemak. Menurut Ayomi (2015) kandungan utama sari buah merah adalah asam lemak. Asam lemak yang terdapat dalam sari buah merah terdiri atas asamr palmitat, asam oleat, asam linoleat, dan asam linolenat. Hasil uji mutu hedonik pada atribut aroma menunjukan bahwa pemberian buah merah pada yogurt probiotik berpengaruh nyata $(\mathrm{P}<0.05)$ secara uji non-paramterik. Yogurt tanpa penambahan buah merah memiliki nilai 1.6 yang berarti beraroma susu lalu penambahan buah merah $2.5 \%$ yaitu 2.33 yang berarti beraoma susu dan penambahan buah merah $5.0 \%$ yaitu 2.93 yang dibulatkan menjadi 3 yang berarti beraroma buah merah. Hal ini dikarenakan

Tabel 5. Uji hedonik dan uji mutu hedonik yogurt probiotik penambahan buah merah

\begin{tabular}{|c|c|c|c|}
\hline \multirow{2}{*}{ Parameter } & \multicolumn{3}{|c|}{ Perlakuan } \\
\hline & $\mathrm{T} 1$ & $\mathrm{~T} 2$ & $\mathrm{~T} 3$ \\
\hline \multicolumn{4}{|l|}{ Hedonik } \\
\hline Warna & $3.23 \pm 0.63 \mathrm{a}$ & $3.17 \pm 0.53 \mathrm{a}$ & $3.10 \pm 0.76 \mathrm{a}$ \\
\hline Aroma & $3.27 \pm 0.45 \mathrm{a}$ & $3.17 \pm 0.59 \mathrm{a}$ & $2.73 \pm 0.59 \mathrm{~b}$ \\
\hline Flavour & $3.13 \pm 0.57 \mathrm{a}$ & $3.20 \pm 0.48 \mathrm{a}$ & $3.00 \pm 0.69 \mathrm{a}$ \\
\hline Kekentalan & $3.03 \pm 0.49 \mathrm{a}$ & $3.10 \pm 0.60 \mathrm{a}$ & $2.73 \pm 0.58 b$ \\
\hline Rata-rata & $3.17 \pm 0.53$ & $3.16 \pm 0.55$ & $2.89 \pm 0.55$ \\
\hline \multicolumn{4}{|l|}{ Mutu hedonik } \\
\hline Warna & $1.00 \pm 0.00 \mathrm{a}$ & $2.03 \pm 0.30 \mathrm{~b}$ & $3.00 \pm 0.27 \mathrm{c}$ \\
\hline Aroma & $1.60 \pm 0.72 \mathrm{a}$ & $2.33 \pm 0.48 \mathrm{a}$ & $2.93 \pm 0.78 b$ \\
\hline Flavour & $2.67 \pm 0.84 a$ & $2.43 \pm 0.57 \mathrm{ab}$ & $2.03 \pm 0.71 \mathrm{c}$ \\
\hline Kekentalan & $3.40 \pm 0.62 \mathrm{a}$ & $2.70 \pm 0.59 b$ & $2.13 \pm 0.97 \mathrm{c}$ \\
\hline Rata-rata & $2.17 \pm 0.55$ & $2.37 \pm 0.49$ & $2.52 \pm 0.68$ \\
\hline
\end{tabular}

P1: T1: penambahan buah merah $0 \%$; T2: penambahan 2.5\% buah merah; T3: penambahan 5\% buah merah; Angka-angka pada kolom yang sama yang diikuti oleh huruf yang sama tidak berbeda nyata pada taraf uji 5\%. Skala uji hedonik yang digunakan yaitu 1 (sangat tidak suka), 2 (tidak suka), 3 (agak suka), 4 (suka), 5 (sangat suka). Skala mutu hedonik yang digunakan yaitu warna : $1=$ Putih susu $2=$ Putih kemerahan $3=$ Merah muda $4=$ Merah, aroma: $1=$ Sangat beraroma susu $2=$ Beraroma susu $3=$ Beraroma buah merah $4=$ Sangat Beraroma buah merah, kekentalan : $1=$ Sangat encer $2=$ Encer $3=$ Kental $4=$ Sangat Kental, Flavour : $1=$ Sangat berasa buah merah 2 $=$ Berasa buah merah $3=$ Beraroma manis $4=$ Sangat Beraroma manis 
buah merah memiliki bau yang khas pada konsentransi tertentu dalam hal ini yaitu 5.0\%.

\section{Warna}

Warna merupakan atribut untuk mengetahui suatu produk disukai atau tidak oleh konsumen. Hal ini dikarenakan respon utama fisiologis dan stimulus objektif indera penghilatan lebih refleks dalam menentukan (Clark et al. 2009). Hasil yang didapat penambahan buah merah tidak berpangruh nyata $(\mathrm{P}>0.05)$ terhadap produk. Penerimaan panelis terhadap produk yogurt pada penambahan buah merah 2.5 dan $5 \%$ berturut-turut bernilai 3.17 dan 3.10 yang berarti disukailebih disukai oleh panelis. Nilai rataan uji mutu hedonik terhadap warna juga memperoleh hasil yang tidak berbeda nyata $(\mathrm{P}>0.05)$ terhadap produk. Penerimaan panelis terhadap produk yogurt pada penambahan buah merah 2.5 dan $5 \%$ berturut-turut bernilai 3.17 dan 3.10 yang berarti disukai.

Hasil uji mutu hedonik menunjukan bahwa penilaian warna pada produk berpengaruh nyata $(\mathrm{P}<0.05)$ secara uji non-paramterik. Yogurt tanpa penambahan buah merah memiliki warna yang putih susu dengan nilai 1.00 lalu yogurt dengan penambahan buah merah $2.5 \%$ memiliki warna putih kemerahan dengan nilai 2.03 dan yogurt dengan penambahan buah merah 5\% memiliki warna merah muda dengan nilai 2.94. Hal ini disebabkan beta karoten yang terdapat didalam buah merah. Makin kuat warna pada tanaman buah merah, menunjukan makin tinggi kandungan karotennya. Hasil penelitian Budi (2001) menunjukan berat rata-rata 2.24 gram sari buah merah mengandung 300 gram ppm betakaroten. Jumlah ini lebih dari minyak sawit yang hanya mengandung 250 ppm (Budi 2004).

\section{Flavour}

Flavour merupakan atribut yang juga penting untuk mengetahui penerimaan suatu produk pada lingkungan masyarakat. Flavour yang kurang disukai akan membuat konsumen tidak ingin membelinya. Flavour dari yogurt probiotik dengan penamban buah merah $2.5 \%$ dan 5.0 $\%$ adalah 3.2 dan 3.0 yang berarti disukai oleh panelis. Flavour ini dapat dikenali dan dibedakan oleh papila. Papila ini dibagi menjadi menjadi 4 yaitu papila fungiform, papila sirkumvalata, papila foliata, dan papila piliform. Pada flavour yogurt ini dikenali oleh papila foliata. Hal ini dikarenakan papila foliata adalah pengecap rasa asam pada lidah (Winarno 2008). Hasil uji mutu hedonik pada atribut flavour menunjukan bahwa pemberian buah merah pada yogurt probiotik berpengaruh nyata $(\mathrm{P}<0.05)$ secara uji nonparamterik. Yogurt tanpa penambahan buah merah memiliki flavour 2.67 yang artinya berasa yogurt lalu yogurt dengan penambahan buah merah $2.5 \%$ memiliki flavour 2.43 yang berarti berasa buah merah dan yogurt dengan penambahan buah merah $5.0 \%$ berasa buah merah. Flavour adalah kesan gabungan rasa dan aroma yang dipengaruhi oleh sifat akustik bahan, tekstur, dan penampakkannya yang diterima oleh indera manusia terutama indera pencicip dan pembau, pada saat makanan dikonsumsi. Buah merah memiliki rasa dan aroma yang khas sehingga panelis dapat membedakan aroma buah merah dan tanpa buah merah.

\section{Kekentalan}

Kekentalan merupakan atribut selanjutnya yang diamati. Kekentalan yang disukai pada yogurt drink ini akan membuat konsumen semakin tertarik untuk membelinya. Penilaian kekentalan dengan skor yang paling tinggi yaitu dengan penambahan buah merah $2.5 \%$ yaitu dengan nilai 3.1 (disukai) dan yang disukai dengan penambahan buah merah 5.0\% dengan nilai 2.73 (tidak disukai). Hal ini berhubungan dengan ekstrak buah merah yang cair. Hasil uji mutu hedonik pada atribut kekentalan menunjukan bahwa pemberian buah merah pada yogurt probiotik berpengaruh nyata $(\mathrm{P}<0.05)$ secara uji non-paramterik.

Yogurt tanpa penambahan buah merah memiliki nilai kekentalan 3.4 yang berarti kental lalu yogurt dengan penambahan $2.5 \%$ memiliki nilai 2.7 yang dibulatkan menjadi 3 yang artinya kental lalu yogurt dengan penambahn $5.0 \%$ memiliki nilai 2.13 yang berarti encer. Hal ini disebabkan penambahan buah merah memiliki kadar air yang tinggi sehingga mempengaruhi mutu produk hingga menjadi cair. kekentalan menunjukan bahwa pemberian buah merah pada yogurt probiotik berpengaruh nyata $(\mathrm{P}<0.05)$ secara uji non-paramterik. Yogurt tanpa penambahan buah merah memiliki nilai kekentalan 3.4 yang berarti kental lalu yogurt dengan penambahan $2.5 \%$ memiliki nilai 2.7 yang dibulatkan menjadi 3 yang artinya kental lalu yogurt dengan penambahan $5.0 \%$ memiliki nilai 2.13 yang berarti encer. Hal ini disebabkan penambahan buah merah memiliki kadar air yang tinggi sehingga mempengaruhi mutu produk hingga menjadi cair.

\section{KESIMPULAN}

Yogurt dengan penambahan buah merah pada taraf 2.5\% masih memenuhi Standar Nasional Indonesia Mutu Yogurt 01-2981-2009. Penambahan buah merah pada yogurt ini mempengaruhi sifat fisik ( $\mathrm{pH}$, viskositas dan TAT) pada maupun uji organoleptik baik hedonik dan mutu hedonik. Berdasarkan hasil pengujian yogurt dengan penambahan 2.5 $\%$ ini yang paling mendekati dengan kontrol. Penambahan buah merah tidak mempengaruhi sifat kimia pada yogurt probiotik ini.

\section{DAFTAR PUSTAKA}

AOAC (Association of Official Analitycal Chemistry). 2005. Official Method of Analysis. 18th Ed. Maryland (US): AOAC International.

Ayomi. 2015. Buah Merah (Pandanus conoideus) terhadap Penyerapan Zat Besi (Fe) dalam Duodenum. J Agromed Unila. [diunduh 2020 November 12] 2(2):90- 93.

[BSN] Badan Standarisasi Nasional. 2009. SNI No 01- 2981-2009. Syarat Mutu Yogurt. Jakarta: Badan Standarisasi Nasional.

[BSN] Badan Standarisasi Nasional. 2011. SNI 01-31412011. Susu Segar. Jakarta: Badan Standarisasi Nasional

Blodgett, R. 2006. Apendix 2. Most Probable Number from Serial Dilution. BAM (Bacteriological Analytical Manual), Chapter 4. FDA (Food and Drug Administration). 
Budi, I. M., \& F. R. Paimin. 2004. Buah merah. Jakarta: Penebar Swadaya.

Budi, I. M. 2001. Kajian kandungan zat gizi dan sifat fisiko kimia berbagai jenis minyak buah merah (Pandanus conoideus L.) hasil ekstraksi secara tradisional di Jayawijaya Irian Jaya. [Tesis]. Bogor: Institut Pertanian Bogor.

Chandan, R. C. 2006. Milk composition, physical and processing characteristics. Manufacturing Yogurt and Fermented Milks. Oxford, UK: Blackwell Publishing, pp. 3-129.

Clark, S., M. Castello, A. Drake, \& F. Bodyfelt. 2009. The Sensory Evaluation of Dairy Product. New York (US): Springer.

Djaafar, T. F., \& E. S. Rahayu. 2006. Karakteristik yogurt dengan inokulum Lactobacillus yang diisolasi dari makanan fermentasi tradisional. Jurnal Agros. [diunduh 2020 Oktober 5] 8(1): 73-80

Donker, O. N., A. Henriksson, T. Vasiljevic, \& N. P. Shah. 2006. Effect of acidificationon the activity of probiotics in yoghurt during cold storage. Int Dairy J. [diunduh november 10] .16: 1181-1189. Doi: 10.1016/j. idairyj.2005.10.008.

Frazier, R. A. 2009. Food Chemistry. Campbell-Plaat G, editor. Food science and technology. Oxford (GB): J wiley.

Indou, Y. 2003. Studi cara pengolahan dan pemanfaatan buah merah (pandanus conoideus) secara tradisonal di kampung Nuhwey Distrik Ransiki Kabupaten Manokwari. [Skripsi] Manokwari: Universitas Negeri Papua.

Insegrad, H. D., \& D. Breithaupt. 2009. Food analysis. Di dalam: Campbell-Plaat G, editor. Food sciene and technology. Oxford (GB): J wiley.

Jay, J. M., M. J. Loessner, \& G. A. Golden. 2005. Modern Food Microbiology. 7 th Edition. Springer, New York.

Ketaren, S. 1986.Minyak dan Lemak Pangan, Edisi 1. Penerbit Universitas Indonesia (UI Press).

Lisangan, M. M. 2005. Pengeringan dan pengemasan untuk memperpanjang umur simpan buah merah. [Tesis]. Bogor: Sekolah Pascasarjana IPB.

Muchtadi, T. R., \& Sugiyono. 1992. Petunjuk Laboratorium Ilmu Pengetahuan Bahan Pangan. Bogor: Departemen Pendidikan dan Kebudayaan Direktorat Jenderal Pendidikan Tinggi Pusat Antar Universitas Pangan dan Gizi Institut Pertanian Bogor.
Nudyanto, A., \& E. Zubaidah. 2014. Isolasi Bakteri asam laktat penghasil eksopolisakarida dari kimchi. J Pangan dan Agroindustri. [diunduh 2020 Oktober 5]. 3(2):743748 .

Permadi, M. R., H. Oktafa, \& K. Agustianto. 2018. Perancangan Sistem Uji Sensoris Makanan dengan Pengujian Peference Test (Hedonik dan Mutu Hedonik), Studi Kasus Roti Tawar, Menggunakan Algoritma Radial Basis Function Network. Jurnal Mikrotik. [diunduh 2020 Oktober 5]. 8(1):29-42. Doi: 10.31598/sintechjournal.v2i2.282.

Rahayu, P., \& S. Nurosiyah. 2008. Evaluasi Sensori. Jakarta: UT Pr.

Renwarin, J. 2002. Budidaya tanaman buah merah dan kuning di kebun koleksi Amban Pantai UNIPA Manokwari. Laporan Penelitian Hibah Bersaing. Manokwari: Universitas Negeri Papua

Robinson, R. K., Tamime, A.Y. Wszolek, \& Monika. 2002. Microbiology of fermented milks. Dairy Microbiology Handbook. 367-430. England (UK): Woodhead Publishing Ltd.

Melanie, R. T., I. I. Arief, \& E. Taufik. 2018. Karakteristik yogurt probiotik dengan penambahan ekstrak bunga rosella (Hibiscus sabdariffa L) selama penyimpanan suhu dingin. Jurnal Ilmu Produksi dan Teknologi Hasil Peternakan. [diunduh 2020 Oktober 5]. 6(1):36-44. Doi: 10.29244/jipthp.6.1.36-44.

Steel, R., \& J. K. Torrie. 1997. Prinsip dan Prosedur Statistik. Jakarta: Penerbit PT. Gramedia Pustaka Utama

Stefani. 2008. Karakteristik mikrobiologi es krim yogurt sinbiotik selama penyimpanan. [skripsi]. Bogor: Institut Pertanian Bogor.

Stepaniak, L., \& A. Fetlinski. 2002. Kefir, Encyclopedia of Dairy Science. Maryland. Academic Press. USA.

Susanto, T., \& S. Yuwono. 2001. Pengujian Fisik Pangan. Surabaya: Unesa Pr.

Syarif, R., \& H. Halid. 1992. Teknologi Penyimpanan Pangan. Jakarta: Arcan.

Tamime, A. Y., \& R. K. Robinson. 2007. Yoghurt science and technology 3rd ed. England (UK): Woodhead Publishing Ltd.

Wahyudi, A. 2008. Bugar dengan Susu Fermentasi. Malang: UMM Pr.

Winarno, F. G., \& I. E. Fernandez. 2007. Susu dan Produk Fermentasinya. Bogor: MBrio Press. 